\title{
Morphometric and meristic characteristics of silver catfish Chrysichthys nigrodigitatus (Lacepède, 1803) (Siluriformes: Claroteidae) from Epe Lagoon, Lagos, Southwest Nigeria
}

\section{Olusegun Olufemi Whenu*, Gabriel Olarinde Mekuleyi and Nimota Ojomu}

Department of Fisheries. Faculty of Science. Lagos State University. Lagos. Nigeria. *Email: olusegun.whenu@lasu.edu.ng.

\begin{abstract}
The morphometric and meristic characteristics of 300 fish samples of silver catfish Chrysichthys nigrodigitatus (Lacepède, 1803) (Siluriformes: Claroteidae) inhabiting the Epe Lagoon, Lagos, was conducted between October 2012 and January 2013 in order to investigate the growth and health status of this species. The meristic characteristics deduced in this study were counted and ranged as follows; dorsal spine had constant value of one all through, and the pectoral spine had a constant value of two, dorsal rays were counted 6-7 $(6.03 \pm 0.25)$, pectoral rays were counted 6-7 (6.04 \pm 0.27$)$, gill rakers were counted $15-18(17.86 \pm 0.96)$, opercula bones were counted 2-4 (3.22 \pm 1.11$)$ and vertebrae count was 8-10 $(8.43 \pm 1.95)$. All the morphometric characteristics except body weight were measured with measuring board of precision of $0.1 \mathrm{~cm}$. Body weight was measured with a metler electronic chemical balance of precision of $0.1 \mathrm{~g}$. Morphometric data includes total length $15.5-38.5 \mathrm{~cm}(25.43 \pm 3.87 \mathrm{~cm})$, fork length $2.0-11.6 \mathrm{~cm}(8.61 \pm 1.53 \mathrm{~cm})$, standard length $10.0-28.3 \mathrm{~cm}$ $(17.85 \pm 3.90 \mathrm{~cm})$, head length $2.0-3.5 \mathrm{~cm}(2.91 \pm 0.79 \mathrm{~cm})$, head depth $1.0-3.3 \mathrm{~cm}(2.41 \pm 1.05 \mathrm{~cm})$, eye diameter $0.5-1.0 \mathrm{~cm}$ $(1.28 \pm 0.77 \mathrm{~cm})$, body depth $1.6-6.5 \mathrm{~cm}(3.57 \pm 0.90 \mathrm{~cm})$ and body weight $24.5-451.6(157.48 \pm 5.60)$. The length and the weight of this species were not directly proportional. Growth parameter has a negative allometric range $(b=0.256)$ and the condition factor $(\mathrm{k})$ ranged from 0.103-2.97 (1.08 \pm 0.64$)$ which indicated a good condition of the fish species in the Lagoon. This study provided baselines of the population structure of this species in Epe Lagoon, Lagos State and also shown that their present growth pattern calls for further monitoring.
\end{abstract}

Keywords: Allometry; Length; Weight; Relationship; Condition factor.

\section{Introduction}

One of the most essential animal protein sources that complement
Received

September 30, 2017

Accepted

February 13, 2018

Released April 30, 2018

Full Text Article



\footnotetext{
ORCID

(D) 0000-0002-8875-5269

Olusegun Olufemi Whenu

(ㄱ) 0000-0002-1030-2518

Gabriel Olarinde Mekuleyi

D 0000-0002-6456-4484 Nimota Ojomu
}

predominantly carbohydrate based diets of Nigerian is fish (Akande, 2011). Due to characterized good flavour, palatability and chemical component of Chrysichthys 
nigrodigitatus (Lacepède, 1803) (Siluriformes: Claroteidae), the demand for its consumption has increased greatly (Offem et al., 2008). Reports have shown that several methods can be effective in determining stock and scientific classification of fish, and one of the commonest method is morphometrc and meristic data (Gallo-da-Silva et al., 1998; Murta, 2000; Saborido and Nedreaas, 2000). Differences in morphometric and meristic characters could indicate variation of growth rate, survival and metabolism in fish (Ezenwa, 1981) and thus help in separation of population of widely distributed species (Diaz et al., 2000; Lawson, 2010). Length and weight relationship (LWR) is also a good method of growth assessment in fish (Arshad et al., 2012). The health status of habitat of fish matters a lot. However, a factor known as condition factor, has been reported to be effective in determining the physiological condition of fish and as well the status of the aquatic ecosystem in which fish live (Oni et al., 1983; Anyanwu and Ugwumba, 2003; Anene, 2005).
Several studies on morphometric characters of some fishes found in Nigeria has been documented (Bagenal, 1978; Anyanwu and Ugwumba, 2002; Eyo, 2003). However, to date, the morphometric and meristic features of silver catfish in Epe Lagoon is yet to be fully reported. The objective of the present study is to examine the growth and status of silver catfish in Epe Lagoon, Lagos, Nigeria, through morphometric and meristic characteristics of the species.

\section{Materials and methods}

\section{Study area}

The geographical location of the study area (Epe Lagoon) is as shown in Figure 1. It is located on latitude $06^{\circ} 31.89^{\prime} \mathrm{N}$ and $06^{\circ} 33.70^{\prime} \mathrm{N}$ and longitude $03^{\circ} 31.91^{\prime} \mathrm{E}$ and $04^{\circ} 03.71^{\prime} \mathrm{E}$. It is bordered by several towns in the North, East and West, and bordered by Gulf of Guinea in the South. The lagoon supports a major fishery in Lagos State (Edokpayi et al., 2008).

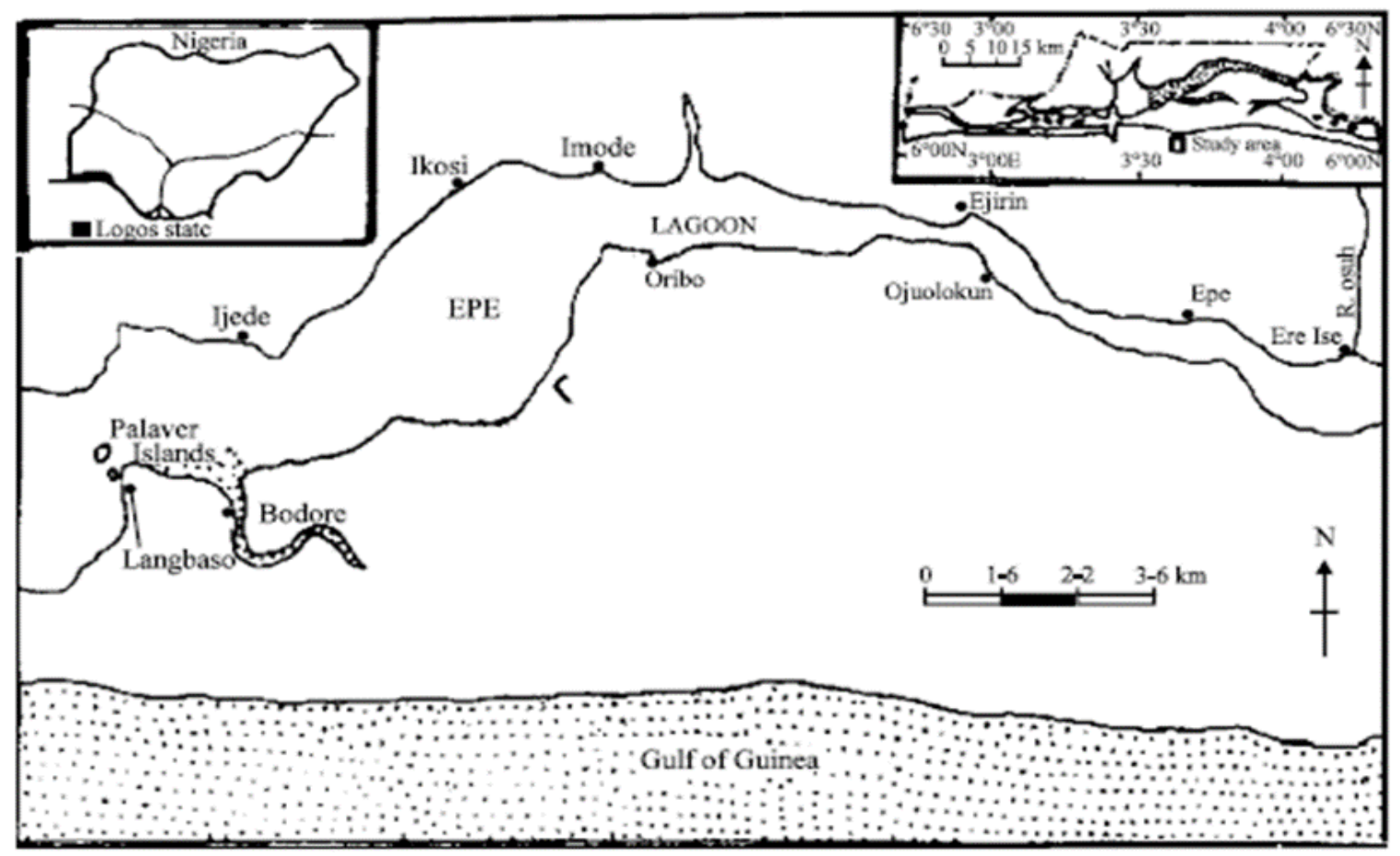

Figure 1. Map of Epe Lagoon in Lagos State, Nigeria. 


\section{Collection of fish samples}

A total of 300 specimens of silver catfish (C. nigrodigitatus) were collected at Epe Lagoon between October 2012January 2013. Immediately after collection, fishes were iced and later freeze at $-20{ }^{\circ} \mathrm{C}$ for storage.

\section{Morphometric measurement}

Prior to measurement, Fishes were defrosted at room temperature $\left(25^{\circ} \mathrm{C}\right)$. Morphometric characters which include body depth, eye diameter, head depth, head length, standard length, fork length and total length were measured with measuring board of precision of $0.1 \mathrm{~cm}$. Body weight (wt) of individual fish was measured with electronic chemical balance of $0.1 \mathrm{~g}$ precision. Description of dimension of each morphometric distance has already been documented in literature (Bagenal, 1978).

\section{Meristic features}

Meristic features which include dorsal spine, pectoral spine, dorsal rays, pectoral rays, gill rakers, opercula bone, and vertebrae were taken by visual inspection and counted in the laboratory but in some cases whereby there are tiny ones, binocular microscope was used to aid counting.

\section{Condition factor}

Condition factor $(\mathrm{k})$ of the fish specimens in this study was determined by using the formulae:

$$
\mathrm{k}=\frac{100 \mathrm{~W}}{L^{3}}
$$

where:

$\mathrm{W}=$ body weight of the fish, and

$\mathrm{L}=$ total length of the fish

\section{Statistical analysis}

Data was processed using Microsoft Office Excel software (Microsoft Office 2010) for length and frequency distribution, and SPPS IBM, version 19.0, for length and weight relationships (LWRs) by plotting natural Log of total length against natural Log of body weight of silver catfish.

Table 1. Meristic counts of silver catfish from Epe Lagoon.

\begin{tabular}{l|c|c|c}
\hline Meristics count & Min & Max & Mean \pm SD \\
\hline Dorsal fin spine & 1 & 1 & $1.0 \pm 0.00$ \\
\hline Soft dorsal fin ray & 6 & 7 & $6.03 \pm 0.25$ \\
\hline Pectoral fin rays & 6 & 7 & $6.04 \pm 0.27$ \\
\hline Pectoral ray spine & 2 & 2 & $2.0 \pm 0.00$ \\
\hline Gill rakers count & 15 & 18 & $17.86 \pm 0.96$ \\
\hline Opercula bone & 2 & 4 & $3.22 \pm 1.11$ \\
\hline Vertebrae count & 8 & 10 & $8.43 \pm 1.95$ \\
\hline
\end{tabular}

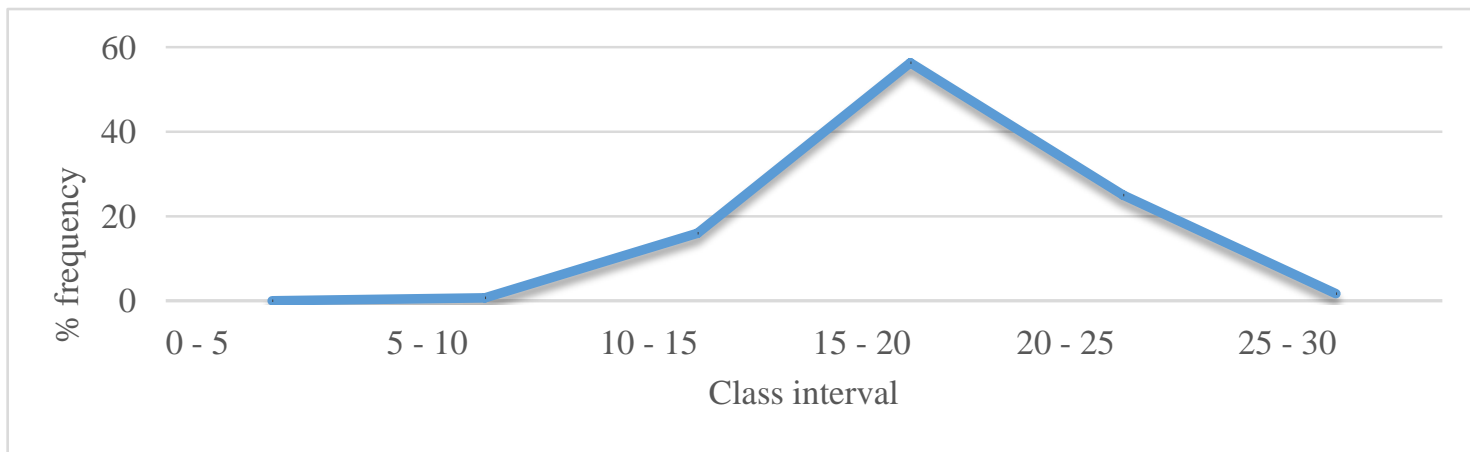

Figure 2. Percentage frequency of lengths of silver catfish from Epe Lagoon. 


\section{Results}

Summary of meristic and morphometric characters of silver catfish from the study area showed that single dorsal spine and pectoral spine had constant values of 1 and 2, respectively, dorsal rays 6-7 $(6.03 \pm 0.25)$, pectoral rays 6-7 (6.04 \pm 0.27$)$, gill rakers $15-18$ (17.86 \pm 0.96$)$, opercula bones 2-4 $(3.22 \pm 1.11)$ and vertebrae were counted 8-10 (8.43 \pm 1.95$) \quad$ (Table 1). Total length ranged between 15.5$38.5 \mathrm{~cm}(25.43 \pm 3.87 \mathrm{~cm})$, fork length varied between 2.0-11.6 cm $(8.61 \pm 1.53 \mathrm{~cm})$, standard length values ranged between $10.0-28.3 \mathrm{~cm}$ $(17.85 \pm 3.90 \mathrm{~cm})$ while body weight was between 24.5-451.6 g (157.48 $\pm 5.60 \mathrm{~g})$ (Table 2). The mean head length was $2.91 \pm 0.79 \mathrm{~cm}$, head depth $(2.41 \pm 0.05 \mathrm{~cm}), \quad$ eye diameter $(1.28 \pm 0.77 \mathrm{~cm})$ while body depth value was $3.57 \pm 0.90 \mathrm{~cm}$. However, the ratios of $\mathrm{HD} / \mathrm{ED}$ was $1.90 \pm 1.48, \mathrm{HL} / \mathrm{ED}$
$2.27 \pm 0.84 \mathrm{~cm}, \mathrm{HL} / \mathrm{BD} 0.81 \pm 0.88 \mathrm{~cm}$, SL/HL $6.14 \pm 0.87 \mathrm{~cm}$, TL/HL $8.72 \pm 1.02$ $\mathrm{cm}, \quad \mathrm{TL} / \mathrm{BD} \quad 7.12 \pm 1.34 \mathrm{~cm}, \mathrm{TL} / \mathrm{FL}$ $2.95 \pm 0.16 \mathrm{~cm}$, and TL/SL $1.42 \pm 1.30$ $\mathrm{cm}$.

Graph of frequency against length distribution of the silver catfish examined in this study revealed that about (55\%) of the fish sampled had standard length which ranged between $15-20 \mathrm{~cm}$ (Figure 2) while $15 \%$ of the fish had between $10-15 \mathrm{~cm}$ standard length. Relationship that existed between body weight and total length of the silver catfish from Epe Lagoon is as shown in Figure 3. The growth coefficient $(b=0.256)$ obtained was less than 3 which indicated that the fish exhibited a negative allometric growth. The regression equation also revealed a very low correlation coefficient $(r)$ value of 0.013 while the condition factor $(\mathrm{k})$ varied between 0.10256 and 2.97 (Table 3).

Table 2. Morphometric measurements and ratios in silver catfish from Epe Lagoon.

\begin{tabular}{lccc}
\hline Morphometric measurements & Min & Max & Mean \pm SD \\
\hline ED & 0.1 & 0.5 & $1.28 \pm 0.77$ \\
HD & 1.0 & 3.3 & $2.41 \pm 1.05$ \\
BD & 1.6 & 6.5 & $3.57 \pm 0.90$ \\
HL & 2.0 & 3.5 & $2.91 \pm 0.79$ \\
FL & 2.0 & 11.6 & $8.61 \pm 1.53$ \\
SL & 10.0 & 28.3 & $17.85 \pm 3.90$ \\
BW & 24.5 & 451.6 & $157.48 \pm 5.60$ \\
TL & 15.5 & 38.5 & $25.43 \pm 3.87$ \\
HD/ED & 0.2 & 20.6 & $1.90 \pm 1.48$ \\
HL/ED & 0.2 & 37.22 & $2.27 \pm 0.84$ \\
HL/BD & 0.67 & 11.17 & $0.81 \pm 0.88$ \\
SL/HL & 0.29 & 8.0 & $6.14 \pm 0.87$ \\
TL/HL & 0.7 & 11.1 & $8.72 \pm 1.02$ \\
TL/BD & 4.78 & 11.67 & $7.12 \pm 1.34$ \\
TL/FL & 0.18 & 1.42 & $2.95 \pm 0.16$ \\
TL/SL & 1.06 & 21.13 & $1.42 \pm 1.30$ \\
\hline
\end{tabular}

TL = Total Length, FL = Focal Length, SL = Standard Length, HL = Head Length, HD = Head Depth, $\mathrm{BD}=$ Body depth, $\mathrm{ED}=$ Eye diameter , and BW = Body Weight. Min = Minimum, Max $=$ Maximum. 


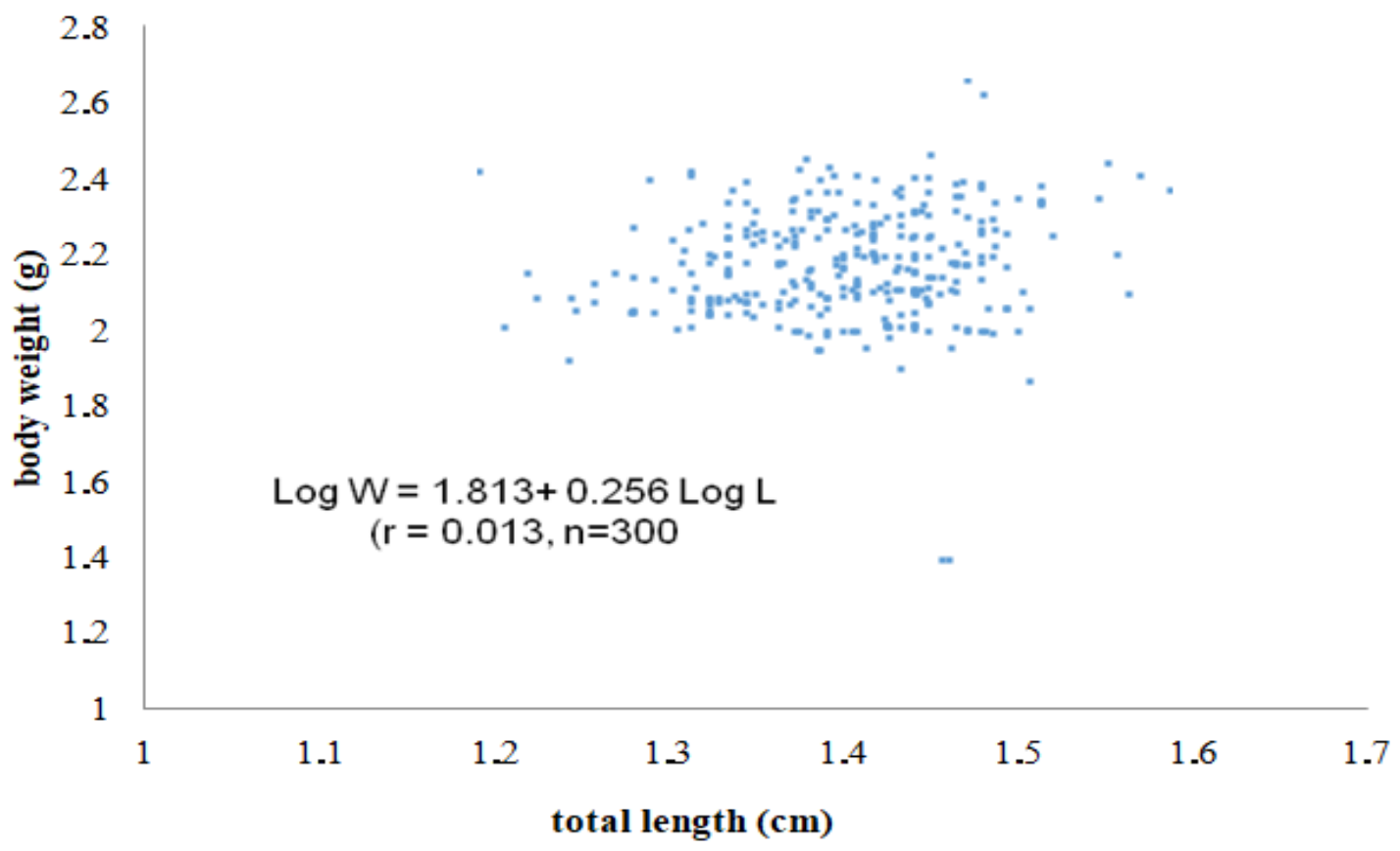

Figure 3. Natural logarithm of total length versus natural logarithm of body weight of silver catfish from Epe Lagoon.

Table 3. Well being of silver catfish in Epe Lagoon.

\begin{tabular}{lcc}
\hline Min & Max & Mean \pm SD \\
\hline 0.10256 & 2.97 & $1.08 \pm 0.64733$ \\
\hline
\end{tabular}

\section{Discussion}

Meristic and morphometric characters of silver catfish Chrysichthys nigrodigitatus in Epe Lagoon was evaluated in this study. The number of dorsal rays, dorsal and pectoral spine of silver catfish being constant indicated identical parental stock. Similar observations had been reported by Eyo (2003) and Ikusemiju (1975) on the species from different locations in Nigeria.

However, there were differences in the vertebrae count of the specimens evaluated in this study. This finding was similar to the differences reported in vertebrae count of Semiontidae, Lepidsosteidae and Ariidae Family by Gallo-da-Silva et al. (1998), but was in contrast with results obtained in Synodontis schall by Adedeji and Araoye
(2006). The standard length-frequency distribution of this fish species showed a unimodal size distribution of which majority of the fish species were in the medium size group $(15-20 \mathrm{~cm})$. This could suggest that they were of the same year class.

Relationship between the weight and length of fish in this study which showed an inverse relation indicated that the species had a negative allometric growth. This could probably occur due to the landing of mainly sexually immature and juvenile fish which are in active growth stages of their lifecycles. This present finding was not similar to the results obtained earlier for the same species in the lagoon (Anyanwu and Ugwumba, 2003; Muyideen et al., 2010) and Cross River (Offem et al., 2008), respectively. The mean condition factor (1.08) obtained in this study is an 
indication of the good condition of the specimens in the study area (Oni et al., 1983; Anene, 2005). The present $\mathrm{k}$ factor was higher than those reported at Badagry Lagoon, Warri River and Imo River, respectively (Ezenwa, 1981).

\section{Conclusion}

The study provided baseline information on the growth pattern and wellbeing of silver catfish in Epe Lagoon. The fish had negative allometric growth and a positive condition factor. Therefore, it could be concluded that silver catfish in Epe Lagoon is presently in good condition. However, further research could be necessary to investigate the factors responsible for its negative allometric growth.

\section{Conflict of interest statement}

Authors declare that they have no conflict of interests.

\section{References}

Adedeji, R. A.; Araoye, P. A. Study and characterization in the growth of body parts of Synodontis schall (Pisces: Mochokidea) from Asa Dam, Ilorin, Nigeria. Nigerian Journal of Fisheries, v. $2 / 3$, No. 1, p. 219244, 2006.

Akande, G. R. Fish processing technology in Nigeria: challenges and prospects. In: Aiyeloja, A. A.; Ijeomah, H. M. (Eds.). Book of reading in forestry, wildlife anagement and fisheries. New Oko Oba, Lagos: Topbase, 2011. p. 772-808.

Anene, A. Condition factors of four cichlid species of a man-made lake in Imo state, Southeast, Nigeria. Turkish Journal of Fisheries and Aquatic Science, v. 5, p. 43-47, 2005. Available from: <http://www.trjfas.org/uploads/pdf_277.pdf >. Accessed on: Aug. 22, 2017.

Anyanwu, A. 0.; Ugwumba, 0. A. Delineation of Pseudotolithus senegalensis (C \& V, 1933) stocks along the east, central and west of the Niger Delta, Nigeria. The Zoologist, v. 1, No. 1, p. 78-85, 2002.
Anyanwu, A. 0.; Ugwumba, O. A. Studies on the morphometric, meristic and electrophoresis patterns of Pseudotolithus species. The Zoologist, v. 2, No. 1, p. 70-77, 2003.

Arshad, A.; Amin, S. M. N.; Nuradiella, Y. L. Z.; Cob, Z. C.; Ara, R.; Aziz, D. Population characteristics of A. japonicas from the Kedah coastal waters of peninsular alaysia. Journal of Fisheries and Aquatic Science, v. 7, p. 162-172, 2012. https://doi.org/10.3923/ jfas.2012.162.172

Bagenal, T. B. Aspects of fish fecundity. In: Gerking, S. D. (Ed.). Ecology of freshwater fish production. Oxford: Blackwell Scientific Publications, 1978. p. 75-101.

Diaz, L. S.; Roa, A.; Gareia, C. B.; Acero, A.; Nava, G. Length-weight relationships of demersal fishes from the upper continental slope off Columbia. The ICLARM Quarterly, v. 23, No. 3, p. 23-25, 2000. Available from: <http://pubs.iclarm.net/Naga/fb2.pdf>.

Accessed on: Aug. 22, 2017.

Edokpayi, C. A.; Uwadiae, R. E.; Asoro, A. O.; Badru, A.E. Phytomacrofauna arthropod associated with the roots of water hyacinth (Eichhornia crassipes) in Epe Lagoon Southern Nigeria. Ecology and Environmental Conservation Paper, v. 14, No. 2/3, p. 241-247, 2008.

Eyo, J. E. Congeneric discrimination of morphometric characters among members of the pisces genus Clarias (Clariidae) in Anambra River, Nigeria. The Zoologist, v. 2, No. 1, p. 1-17, 2003.

Ezenwa, B. A. Study of the reproductive biology of the catfish, silver catfish (Lacepede, 1803) in Nigeria. Lagos, Nigeria: University of Lagos, 1981. (PhD thesis).

Gallo-da-Silva, V.; Cavalcanti, M. J.; Lopes, P. R. D. Comparative morphometrics of Semiontidae, Lepidsosteidae and Amiidae (Actinopterygii: Neopterygii) by multivariate analysis of truss networks. Anais da Academia Brasileira de Ciencias, v. 70, No. 1, p. 117-124, 1998.

Ikusemiju, K. Aspect of the ecology and life history of the sculpin, Coitus aleuticus (Gilbert) in Lake Washington. Journal of Fish Biology, v. 7, No. 2, p. 235-345, 1975. https://doi.org/10.1111/j.10958649.1975.tb04595.x 
Lawson, E. O. Morphometric measurements and meristic counts in mudskipper (Periophthalmus papilio) from mangrove swamps of Lagos Lagoon, Nigeria. Journal of Applied Biosciences, v. 34 , p. 2166-2172, 2010. Available from: <http://www.m.elewa.org/JABS/2010/34/5. pdf>. Accessed on: Aug. 22, 2017.

Murta, A. G. Morphological variation of horse mackerel (Trachurus trachurus) in the Iberian and North African Atlantic: implications for stock identification. ICES Journal of Marine Science, v. 57, p. 12401284, 2000. https://doi.org/10.1006/jmsc. 2000.0810

Muyideen, O. L.; Oluwabamise, J. S.; Bola, M. S. Morphometry and diet of Chrysichthys nigrodigitatus (Lacepède, 1803) in Epe Lagoon, Lagos, Nigeria. African Journal of Biotechnology, v. 9, No.46, p. 7955-7960, 2010. Available from: <http://www.aca demicjournals.org/article/article138062808 9_Lawal et al.pdf>. Accessed on: Aug. 22, 2017.

Offem, B. O.; Akegbejo-Samsons, Y.; Omoniyi, I. T. Diet, size and reproductive biology of the silver catfish, Chrysichthys nigrodigitatus (Siluriformes: Bagridae) in the Cross River, Nigeria. Revista de Biología Tropical, v. 56, No. 4, p. 1785-1799, 2008. Available from: <http://www.scielo.sa.cr/pdf/rbt/v56n4/art 16v56n4.pdf>. Accessed on: Aug. 22, 2017.
Oni, S. K.; Olayemi, J. Y.; Adegboye, J. D. Comparative physiology of three ecologically distinct freshwater fishes, Alestes nurse Ruppell, Synodontis schall Bloch \& Schneider and Tilapia zilli Gervais. Journal of Fisheries Biology, v. 22, no. 1, p. 105-109, 1983. https://doi.org/10.1111/j.1095-8649.1983. tb04730.x

Saborido, R.; Nedreaas, K. H. Geographic variation of Sebastes mentella in the Northeast Arctic derived from a morphometric approach. ICES Journal of Marine Science, v. 57, p. 965-975, 2000. https://doi.org/10.1006/jmsc. 2000.070 